Article

\title{
Gender and Superstition in Modern Chinese Literature
}

\section{Gal Gvili}

East Asian Studies, McGill University, Montréal, H3A 1W9, Canada; gal.gvili@mcgill.ca

Received: 24 July 2019; Accepted: 30 September 2019; Published: 21 October 2019

\begin{abstract}
This article offers a new perspective on the study of the discourse on superstition (mixin) in modern China. Drawing upon recent work on the import of the concept "superstition" to the colonial world during the 19th century, the article intervenes in the current study of the circulation of discursive constructs in area studies. This intervention is done in two ways: first, I identify how in the modern era missionaries and Western empires collaborated in linking anti-superstition thought to discourses on women's liberation. Couched in promises of civilizational progress to cultures who free their women from backward superstitions, this historical connection between empire, gender and modern knowledge urges us to reorient our understanding of superstition merely as the ultimate other of "religion" or "science." Second, in order to explore the nuances of the connection between gender and superstition, I turn to an archive that is currently understudied in the research on superstition in China. I propose that we mine modern Chinese literature by using literary methods. I demonstrate this proposal by reading China's first feminist manifesto, The Women's Bell by Jin Tianhe and the short story Medicine by Lu Xun.
\end{abstract}

Keywords: superstition; religion; modern; China; imperialism; gender; civilization; Jin Tianhe; Lu Xun

\section{Introduction}

In 1941, Xu Dishan (1894-1941), one of the well-known writers of the May Fourth generation, co-founder of the most important literary association in Republican China-the Literary Research Association (wenxue yanjiu hui)—and a notable scholar of Buddhism, Daoism, and Folklore, published what would become his final written work: A Study of Spirit Writing Superstition (fuji mixin di yanjiu). Literally meaning "wielding the planchette", spirit writing is a practice by which other-worldly beings are perceived to communicate with this world through writing, using a stick affixed in a sieve that traces characters in sand or ashes or a brush attached to a tree branch through which characters are written on a piece of paper. ${ }^{1}$ A Study of Spirit Writing Superstition remains a pioneering study in this practice. $\mathrm{Xu}$ Dishan explored various articulations of spirit writing in Chinese genres such as pen jottings (biji) and accounts of the strange (zhiguai). Most striking in this work, nevertheless, is Xu Dishan's account of his motivation for researching and writing on this topic. In the conclusion, he states that what inspired him to write a study of "the superstition of spirit writing" was the fact that the practice is growing ever more popular in China in his time, allegedly touted as an era of science and rationality (1). Xu Dishan declared that communication with other realms beyond this world (jiaogan)—such as people who believe things happens during spirit writing activities-is a human need, and it did not vanish in the modern era. Since the practice of spirit writing hinges upon the

1 The use of the brush in spirit writing is a later practice, according to Zeitlin (1998). As Zeitlin notes, scholars have documented history of spirit writing in China (fn 2), but Xu Dishan wrote the first comprehensive study of this phenomenon. 
practitioner's belief that there are thresholds of existence beyond this world, Xu Dishan concluded, the superstition of spirit writing belongs to the realm of religion, which is also rooted in substantiating a connection between this world and the otherworldly (Xu 1945, p. 74). Xu Dishan spent about two decades researching Buddhist and Daoist texts, and studying the history of Christianity in China. For this purpose, he traveled widely, consulting archives in China, the US, England and India. He also converted to Christianity at a young age. What do we make of the fact that one of the most prominent scholars of religion studies in the Republican era equated religion and superstition-effectively locating a "folk" practice in the same realm as more institutionalized, scripture-based religion? By collapsing the boundaries between "religion" and "superstition", Xu Dishan undermined a modern view, which was popular at the time in scholarly circles as well as in state apparatuses: that humans evolved from practicing superstitions to faith-based religions, from magic into text-based systems ${ }^{2}$. By upholding the persistence of superstitions in the modern era, $\mathrm{Xu}$ Dishan was very much ahead of his time. His work anticipated recent scholarly arguments that the narrative of modern disenchantment is faulty and that we must look more seriously at a nineteenth and early twentieth century discourse on superstitions to obtain a broader and more nuanced view of modern history and of the role of religion in that history (Margel 2005; Josephson Storm 2017).

The following essay takes Xu Dishan's collapsing of the boundary between religion and superstition as its point of departure. I seek to investigate how the idea of superstition unfolded in modern China as a multilayered site that is simultaneously condemned and re-inscribed into culture via the persistence of the human need for communication with the beyond. For this purpose, I propose that we examine the notion of superstition, as it is manifested in modern Chinese literature. My essay consists of three parts: I begin by a brief survey of recent scholarship on superstition. While the first iterations of the notion superstition can be traced to the Greco world, a robust discourse on the term "superstition" formed and spread exponentially during the nineteenth century, as part and parcel of colonial modernity. To the current scholarship on superstition, hailing from history, anthropology, and religion studies, I propose adding a new archive of literary texts. Modern literature, which formed during the imperial era of the nineteenth century around the world grappled substantially with the notion of superstition. Yet, in the study of discourses of superstition, modern literary texts have not received much scholarly attention as did state documents or religious tracts. In the second part, I shift my focus to late Qing and Republican China, and show how in the Chinese context, the discourse on superstition was deeply gendered. During the 19th century, as part of new knowledge introduced in colonies and in areas encroached by European and American empires, a rhetoric of progress and civilization furnished accounts written by missionaries, convers and reform-minded intellectuals, which portrayed women as prone to superstitions, and thus as a hindrance to the progress of their societies. Modern writers grappled, through female characters, with the aporia between the episteme of scientific objectivity, and the persistence of a culture of supernatural which they could not simply turn their backs to. In the third part of this essay, I will demonstrate my proposal to approach superstition through a gendered reading of Chinese literature by closely reading what is perhaps the most well-known anti-superstition story in the modern Chinese canon, Lu Xun's Medicine (藥 Yao (Lu 1981)). Though I envision this essay as a proposal to reexamine modern Chinese literature's engagement with superstition broadly, for considerations of space and in order to present a cogent demonstration, I limit myself here to one substantial text which I analyze thoroughly. The overall goal of this essay is to reveal a distinctively modern nexus in which superstition, gender, and literature triangulated and to suggest that we explore

2 Seminal in grounding the perception that humanity developed from magic to religion was the folklorist James Frazer's work The Golden Bough: A Study in Magic and Religion (Frazer 1993), but one can think of many more. The emergence of Comparative Religion in the late 19th century-a discipline which defined ten world religions and thus relegated the rest to the realm of superstition - was a key historical moment in the cementing of this episteme. Figures such as Émile Durkheim, Max Müller, E.B Tylor and others all echoed versions of an evolutionary view which grounded human development away from magic-based paganism into faith-based Christianity. See Masuzawa (2005); Styers (2004). 
this nexus further in order to learn not only about late Qing and Republican era China but about the different power structures that came into play in a global preoccupation with superstitions in the modern era.

\section{The Modern Discourse on Superstition}

My current attempt to open up our understanding of superstition in modern China to new consideration joins a growing interest in recent years across disciplines from history and religion studies to anthropology and political science in the study of the social function of superstition in history. Dale Martin, for example, (Martin 2004, p. 3) develops a genealogy of the term "superstition" in Europe and shows how at the time of the Roman Empire, the term "superstition" was first used to designate Christians who practiced an unrecognized religion that was considered heretic. This type of understanding of superstition as heresy is not unique to the West in any way, and in China, as Rebecca Nedostup reminds us in her seminal study on the Chinese state's anti-superstition legislation during Nanjing Decade (1927-1938) (2010), the imperial era employed various categories to demarcate heresies, such as orthodox (zhengjiao) and heterodox (xiejiao). Yet, while the history of institutional distinction between orthodoxy and heterodoxy is long and ubiquitous, the term "superstition" - etymologically drawn from the Latin superstitio-gained particular traction during the 19th century. Several recent studies detect a particular shift in the definition and the circulation of the notion of superstition during the 19th century, at the historical watershed which saw the death of Hegel and rise of positivism along with the rapid expansion of the global Christian mission. This line of inquiry demonstrates how the modern concept of superstition came to stand as the evil twin of religion-a terrain in which the animistic, magical and ghostly are all collapsed, in contrast to "religions of the book" which scriptural anchorage and monotheism located them on a higher rung on the evolutionary ladder. While historical positioning of the term superstition as the irrational other of religion has been established, it bears repeating, especially for contemporary audiences, or, from my own experience, college students, who still respond "science" when asked, "What is the opposite of superstition?" This historical narrative was first established in 2005 by Serge Margel in the seminal 'Superstition' and since has inspired scholars like Anidjar (2006) and most recently reiterated Josephson Storm (2017). Josephson Storm is mainly interested in dispelling the narrative of modern disenchantment by revealing a series of historical convergences of religion and science, but in the process, he delineates a useful timeline in which the modern understanding of religion as a faith-based system emerged in contrast to superstition and in accordance with science. According to Josephson Storm, only in the second half of the 19th century science and religion congealed as (seemingly) separate "discursive systems" (14).

To summarize, the scholars mentioned above argue that modern thinkers re-introduced the term superstition not as heresy, as it was understood before the 19th century, but rather as the illogical, primitive and false other of "religion." The yardstick for determining which religions would be recognized as such, was, not surprisingly, Protestant Christianity. In this categorization of the world into religions and their sinister others, Protestant missionaries collaborated with imperial forces in establishing clear boundaries of religious worship. Perhaps the strongest evidence of the missionary-imperialist collaboration lies in the propagation of the notion "Christian Civilization" (Stanley 1990) to bolster the imperial powers program for civilizing the barbaric frontiers (Conroy-Krutz 2015). In order to distinguish the missionary notion of religion from the local practices of worship, the label of "superstition" was assigned to all religious structures that did not meet the criteria established by the new discipline of Comparative Religion, which was based on Protestant models (Ni 2015).

In nineteenth and early twentieth century Asia, a new discourse on superstition was disseminated via a colonial epistemology, which favored binary oppositions such as civilization and barbarism or democracy and despotism (Ashiwa and Wank 2009). While China, unlike nineteenth century India, or Egypt, was not a colony per se, the series of unequal trade treaties which the Qing government was forced into signing with European powers in the aftermath of the Opium Wars (1839-1942; 1856-1860) ensured the constant presence in China of missionaries, educators diplomats and traders. Many of 
them saw the imperial civilizing mission, which was put into effect in colonies, especially in India, as absolutely pertinent to China. ${ }^{3}$ Protected by the treaties, they were able to disseminate knowledge and texts that were the backbone of colonial modernity.

The modern concept of "superstition" was translated into Chinese from modern Japanese using the characters 迷信 which are romanized mixin. The compound mixin has appeared in Chinese texts earlier, but scholars generally agree that by late nineteenth century and early twentieth century, mixin appears more frequently than before and the meaning allotted to this term has shifted as well-now indexing the Western concept "superstition".

In a recent study, Huang (2016) offers a comprehensive survey of research on the history of mixin appearances in Chinese language historical documents. The first ones, which were rather scattered and rare, date to the Tang dynasty era (618-907). The term mixin is found on a tomb inscription and in Buddhist sutras, in both cases denoting heretic, dangerous popular beliefs that counter Confucianism or Buddhism by leading the population into mixin- "believing blindly" (Huang 2016, p. 59). By the seventeenth century, Jesuit missionaries serving in the imperial court and Chinese Christian converts began to use mixin more frequently in their writings. Chu (2018) notes that Jesuits often used "superstitio" to discuss Chinese practices such as burning paper money in their writings, and that at the same time we begin to notice Chinese converts using mixin to refer to Chinese teachings (jiao) as heretic, in attempt to foreground Christianity. Chu thus surmises that Jesuits and Chinese converts co-authored mixin as designating non-Christian teachings in the seventeenth century.

By the late Qing, particularly the first decade of the twentieth century mixin began to appear more frequently in Chinese documents including articles in journals and newspapers such as Shenbao, Shixuebao, Dongfang zazhi and others, as well as in fiction and tracts written by missionaries and Chinese converts (Goossaert and Palmer 2011, p. 52). At this time, mixin no longer meant heresy or non-Christian teaching, but was ingrained in the modern meaning I mentioned above: denoting various practices of ritual and worship that did not fall under the rubric of "religion." For missionaries, the binary of "religion" and "superstition" was viewed as an evangelizing aid. For imperial powers, this binary served as a practical tool of governance. Most recently, the journal Method and Theory in the Study of Religion (Hughes and Ramsey 2018) has devoted an issue to the study of the modern discourse on superstition in various colonial settings including but not limited to Haiti, Vietnam, and the Philippines. In all of these locales, the concept of superstition served missionaries to evangelize and governments to regulate local populations. I will state a few quick examples to demonstrate the broad geographical purview of this practice. In the Philippines during the last decades of the 19th century, US civil and military officials banned the use of charms called anting anting which were worn on the neck and believed to possess supernatural powers. This ban was perceived as part of a civilizing mission and as a mean of population control, preventing "mobs of irrational resistance against rational rule" (Wheatley 2018, p. 30). Emily Conroy-Krutz tracked missionary work in 19th century Hawaii and showed how criticism hurled by foreign traders and missionaries played a significant role in the abolition of the kapu (taboo) system in 1819 (Conroy-Krutz 2015, pp. 122-23). In the aftermath of the Haitian Revolution (1791-1804), the independent government banned ritual practices as superstitions, in attempts to combat images of primitive Haiti which Europe and the US promoted to justify ostracizing the newly formed nation (Ramsey 2011).

In China, after losing the first Sino-Japanese War (1895), Chinese reformers believed that the Japanese adoption of state Shintō secured their victory (Kuo 2013). Beginning in 1901 with the New Policy reforms of the late Qing (Xinzheng) and throughout the Republican era, China has seen

3 Missionaries in China turned to the experience of their more seasoned peers in India to learn how to strategize for evangelizing. Journals such as The Chinese Recorder contain many advertisements for reading primers or Christian education materials which mention that these materials have already been proven useful in India. Notably, the missionary John Murdoch (1819-1904) formed in India a Christian Literature Society for India, and after conducting two visits to China, his colleagues there established a Chinese branch of the Society. 
consistent state-sponsored attempts to eradicate various religious formations which were dubbed superstitions-from movements to destroy temples in order to build schools (Duara 1995) to monitoring and banning sects (Nedostup 2014). During the late Qing and throughout the Republican era, a discourse on superstition gained popularity in different contexts of writing, from state legislation and campaigns banning religious formations as forms of superstitions, to essays committed to studying superstitions in the foundational Folklore Studies journal Geyao Zhoukan (1922-1925), to modern fiction's condemnation of traditional Chinese medicine and burial practices as superstitions. Mixin became not only a discursive formation but a course of academic study. In 1927, the Chicago University trained scholar of Comparative Religion and former Peking University professor Jiang Shaoyuan (1898-1983) established a course on "superstition studies" in the Chinese Department at Sun Yat-Sen University in Guangzhou. Jiang continued to publish about the need to study and research superstition, appealing, for example, in 1930, to educators and writing: "Schools for general education [secondary schools] should add a class on superstitious studies, with the aim of giving students a clear understanding of popular superstitions in Chinese society today, why such superstitions are superstitions, and how modern science can help us see through them, as well as giving us accurate notions and effective doctrines to replace them ${ }^{4 \prime \prime}$.

Historians of modern East Asia who have examined the discourse on superstitions attempt to periodize the use of the term mixin in Chinese and to track its meanings as manifested predominantly in state legislation. In this context, Josephson (2012) and Nedostup (2009) argue, that the term "superstition" appeared in Japanese for the first time in 1853 in communication between magistrate of Uraga and American warships. "Superstition" was translated into Japanese as meishin by Protestant missionaries who contrasted "superstition" to "religion-" (read: Christianity) and received protection under the auspices of the trade treaties forced upon the Japanese. The Chinese compound mixin was a translation of the Japanese characters for meishin (迷 信) sometime during the Qing dynasty. However, the so-called "arrival" of the term superstition into Chinese language is harder to pinpoint.

Scholars of modern China cite Bastid-Bruguière's argument (Bastid-Bruguière 1998) that the modern understanding of mixin was first introduced into Chinese by Liang Qichao in 1902 (Goossaert and Palmer 2011). This periodization is problematic for two main reasons. First, in its modern iteration the term mixin appears in earlier documents such as newspaper articles, (I found an example 1897 in an article on the superstition of solar eclipse in xueshibao, Broy (2016) found an 1888 example from shenbao - one can probably found even earlier examples). Second, in its various manifestations, including Liang Qichao's 1902 essay To Defend Confucianism Is Not The Way to Revere Confucius (Bao jiao fei suoyi zun kong lun), which Bastid-Bruguière relies on, mixin did not carry a singular meaning. For example, both Liang (1999) and Hu (1922), two of the most well-known figures of the May Fourth era argued that religion is a type of superstition. ${ }^{5}$ Others, like Liang Qichao's teacher, Kang Youwei, viewed the idea of religion as a source of national strength and admonished local practices of worship in temples as dangerous superstitions (Kuo 2013; Goossaert 2006). Put briefly, we seem to neither know when did the term superstition entered China, nor what did it exactly mean, in one or another time period.

What I take from the historical scholarship on superstition in modern China is a methodological question which the above-mentioned engagements with periodization and definition raises for the field of area studies. The question is this: does periodization (assuming for a minute that it's feasible) prove effective to study how colonial discursive constructs circulated in the modern era? Can we perceive of another method to account for the intricate ways in which a discourse on superstition engaged with local contexts? This is a much-needed enterprise, I think, not only because the finality of periodization can be faulty, but also, and perhaps more so, because the imperialist epistemology

4 Translated and cited in (Huang 2016, p. 72). See Huang for an elaborate discussion of Jiang Shaoyuan's work.

5 Hu Shi writes (Hu 1922): "Every religion demonstrates three aspects: moral teachings, theological theory and superstitions. The Chinese people, mainly due to flawed education are particularly receptive to the superstitious aspect, not to theology". 
embedded in discursive constructs such as "superstition" which modern Christianity exported, simply cannot be contained within one narrative. If the myth of a unitary Western modern disenchantment had been refuted conclusively (Blumberg 1985; Latour 1993), why do we often seek a unitary story in which Asia "awoke" at a particular point in time to reason, science, and the nation ${ }^{6}$ ?

Here, I believe that methodology drawn from literary studies can help us extract the multi-layerdness of the discourse on superstition. My suggestion is two-fold. First, I propose that we add a new archive to the ones used to study superstition in modern China-namely, the above-mentioned documents concerning state legislation, Christian tracts, journal and newspaper essays-by paying attention to how literature engages with the tension between folk practices and modern knowledge. Second, I propose we mine the literary archive by employing literary analysis. Put simply, I suggest we read like scholars of literature: that we pay attention to questions of form, to contradiction between literal content and underlying narrative structures and to the multiplicity of voices. Literary expression does not strive to locate a unified ontology. By its nature, fiction engages several thresholds of reality. It demands of its reader to suspend their disbelief and follow a world that is not real but is still believable. For this reason, literature strikes me as a potentially powerful medium for learning about transnational discursive constructs such as superstition. A focus on literary texts and the use of literary analysis enables us to eschew the tiringly familiar binary of enchantment and disenchantment in favor of exploring how notions such as superstition came to inform a view of the world and relations of power. In fact, a focus on modern Chinese literature's engagement with superstitions immediately exposes us to the ways in which power is inscribed in society. Predominantly, when we read Republican era literary representation of superstitions, a particular literary type emerges from pages upon pages of fiction: the illiterate superstitious woman.

\section{Women and Superstitions in the Modern Idea of Civilization}

Modern and contemporary Chinese literature is replete with representations of women practicing superstitions. In Xu Dishan's Yu Guan (玉 官 1939) the protagonist, who gives the novella its name, wanders the earth carrying the Bible to protect her from Western ghosts and the Book of Changes for protection from Chinese ghosts. In Ba Jin's Family (家 Jia 1933) the reader is drawn to the character of Ming Feng, a young bondmaid who commits suicide while believing the afterlife harbors a better future, and is lamented by her bondmaid friends who burn paper money for her safe journey in the afterlife. Xianglin's wife in Lu Xun's Prayers for Blessings (祝福 Zhufu 1924) haunts the narrator and the reader in turn, with her enduring question: can family members unite after death? The sorcerous midwife in Yu Hua's World Like Mist (世事如煙 shi shi ru yan), Xiao Qian's fortune telling aunt in Traveler Without a Map (未帶地圖的遊人 wei dai ditu de youren, originally published in English in 1990), Female characters believing in flesh eating female ghouls in Nieh Hualing's Mulberry and Peach (桑青與桃紶 Sang qing yu tao hong Nieh 1976), to state just a few examples ${ }^{7}$. We should note that female characters who engage in occult practices such as shamanism, witchcraft, and fortune telling did not suddenly emerge in the modern era-they inhabit premodern Chinese literature as well as

6 There are important and notable studies that go against this narrative, such as Dipesh Chakrabarty's Provincializing Europe (Chakrabarty 2000) which makes a case for understanding modern Indian history beyond the paradigm of the secular modern. In the context of China Pang Laikwan examined how magic culture came to mediate the Chinese experience of modernity (Pang 2004). Yet, the devious ways in which imperial powers propagated that the dialectic of enchantment and disenchantment is the epitome of modern civilization and how this rationale was used to further exploit colonies and semi-colonies economically still awaits attention from Area Studies scholars.

7 In fact, a discourse on superstition remained persistent throughout the Maoist era as well as in the 1970's and 1980's, but in this essay, I am concerned with the Republican period as a significantly formative moment. Ni Zhange's essay that is forthcoming in this special issue offers a different approach to the study of how Chinese literature grapples with representing superstition as a critique of neo-liberalism. My essay complements hers as she is dealing with several texts dating to the contemporary period. Together, both essays testify to the new and exciting direction current scholarship on superstition in Chinese literature is taking, and to the breadth of its engagement. 
other literatures around the world, both modern and premodern ${ }^{8}$. Yet, while in premodern Chinese literature stock characters of shrews and sorcerers were contained in specific genres (Cass 1999), in the May Fourth era, as Chinese writers opted for freer genres in modern fiction at the same time in which practices of folk religions were branded as superstitions, the connection between women and the superstitions became more pervasive, more pronounced and much more specific.

I considered above the collaboration between missionaries and legislators in cementing the equation of superstition with barbarism and of religion with civilization in the imperialist era. Central to this 19th century binary thinking was what came to be known as, "The Woman Question." "The Woman Question" emerged in Victorian England in relation to a new developmental view of history (Crosby 1991) and was developed in the writings of key figures in political theory, thinkers, most famously Mill (1869) and Spencer (1851). However, "The Woman Question"—a notion committed to defining anew the role of women in industrialized societies-circulated much more broadly than England, spanning Asia, the middle East and the Americas. ${ }^{9}$ In its global circulation, "the woman question" pinpointed the condition of women as a touchstone for a culture's level of development from barbarism to civilization. As Towns (2009) has shown, the condition of women in a certain country came to serve as a crucial yardstick for European empires' assessing the country's level of civilization and whether or not this particular culture is deemed fit to enter what was termed "society of civilized states." Significantly, British and American suffragists actively promoted the equation between a culture's level of civilization and the condition of its women. In her "Address on Women's Rights (1848)—" one of the foundational texts of American suffragism—Stanton (1997) addressed her audience in these words:

As the nations of the world emerge from a state of barbarism, the sphere of women gradually becomes wider but not even under what is thought to be the full blaze of the sun of civilization is it what God designed it to be ... There is a class of men who believe in the natural inborn, inbred superiority both in body and mind and their full complete Heaven descended right to lord it over the fish of the sea, the fowl of the air, the beast of the field, and last tho' not least the immortal being called woman ... We seldom find this class of objectors among liberally educated persons, who have had the advantage of observing their race in different countries, climes, and under different phases, but barbarians tho' they be in entertaining such an opinion-they must be met and fairly vanquished. (Gordon 1997, pp. 96-98)

Stanton, an avid Protestant, subsumed women's rights under the barbarism/civilization binary. This 19th century episteme, thus, not only furnished imperialism, but proved pliable enough to sustain comfortably colonial expansion and women's rights (Sneider 2008). It should come as no surprise, then, that the first organized promotions of women's rights in colonies and semi-colonies like India, China and Egypt were established by (male and female) Protestant missionaries clamoring against "barbaric" practices such as foot-binding, sati (widow immolation) and preventing women from accessing education. These missionaries prompted local male intellectuals who became enthralled with the ideal of an independent nation - an equal member in the society of civilized nations—and struggled for its founding. In a variety of cultures, languages, and locales, the woman question was picked up by these male reformers as the most critical item on their agenda, for proving that their culture is civilized and that they are worthy of national independence. Between foreign colonizers and local nationalists, the woman question became a national problem par excellence and an urgent one at that (Ko 2007; Pollard 2005; Chatterjee 1989). Solutions to the problem, as reformers suggested,

8 The link between women and practices including fortune telling, shamanism witchcraft and spirit possession spans cultures all over the world and raises important questions regarding the female body that functions as a porous medium of communication with the beyond (Federici 2014).

9 On the emergence of this discourse in China see (Judge 2008). 
were varied and context specific, from eradicating foot-binding and polygamy to raising levels of female literacy.

Moreover, in the process of making women into a national problem of uttermost urgency to reform-minded intellectuals across Asia, various definitions of the female nature circulated in essays, research and fiction. Folklorists argued that women harbor primordial sentiments-unscathed by politics or education - and sought to study tales and folksongs which featured female figures to flesh out an understanding of national character (Lee 2005). Reformers promoting the ideal of "good wife wise mother-" immensely popular in East Asia in the end of the 19th century-defined women as the pillars of the nation: responsible for rearing national citizens and maintaining a wholesome household (Uno 2005; Choi 2009a). Others viewed women as parasites: benefiting throughout history from male labor without contributing to the household economy (Liu et al. 2013). In these various views of what women are and what they should do to elevate themselves and their nation, the woman question and the discourse of superstition converged: women were theorized as prone to superstition by nature, and both "woman" and "superstition" featured prominently in programs of national strengthening as hindrances which the fledgling nation must overcome. ${ }^{10}$

In China studies, the focus on women as an ultimate other personifying both a desired national sentiment and a despised backward attachment to superstitions has only recently gained traction. ${ }^{11}$ In this context, we should note Haiyan Lee's recent The Stranger and the Chinese Moral Imagination (Lee 2014) in which Lee discusses the figure of woman in May Fourth literature. Lee doesn't engage superstitions per se, but she focuses on women who traverse the boundaries between orthodox and heterodox realms of society-as courtesans, sorcerers, and religious worshippers. These women mediate, Lee argues, the aporias of modern existence and the May Fourth anxieties over an enlightenment project which is a fait accompli. Thus, these transgressive female characters facilitate the formation of a modern Chinese male subjectivity. Lee's observation that the May Fourth enlightenment project failed at upholding a radical divide between superstition and science and that the figure of woman in literature shows this to us is significant. It is significant because, as I noted before, dispelling the idea that disenchantment happened - that superstitions were ever eradicated by science or religion or both is not enough, and only by excavating the ways these discourses worked and did not work-their aporias-can we begin to gain an understanding of what did the failed disenchantment project actually produce.

\section{Gender as Method for Studying Superstition in Chinese Literature}

Female characters in literary texts are a good a starting point for examining the ways in which the modern concept of superstition inscribed a particular characterization of women. But if we wish to read for the multiple ways in which superstitions animate the modern literary work in China-beyond representation schemes and characterization, I suggest that we examine "gender" as a category with which to analyze texts. Though these two categories are often times conflated, there are notable differences between women and gender. Here I rely on Scott (1986) canonical distinction, that gender is a constitutive element of social relationship and a way of signifying relationships of power. Since the publication of Scott's pioneering essay, the distinction between gender studies and women studies has

10 We see this link between women and superstition in different locales in Asia and the Middle East. Overwhelmingly, this link was established by Protestant missionaries and was propagated via missionary journals articles, teaching aids and in school lectures. In her work on female Korean converts, for example, Hyaeweol Choi demonstrates how well this link was internalized, as she brings up the case of Pahk Induk (1896-1980). A model student in missionary schools, Pahk, echoed her missionary teachers in her writing about rural Korean women: "Having grown up in the country I know somewhat the life of a farmer's wife. She exists within the four walls of poverty, ignorance, disease and superstition" (Choi 2009b, pp. 161-62).

11 In Chinese language scholarship I didn't find studies which critically explore the connection between gender and superstition although several scholars in recent decades had been challenging the enlightenment May Fourth narrative and explore the connections between religion and literature. Others had looked into mixin and late Qing literature more directly (Wang 2017; Yi 2013). 
been solidified by other scholars working in queer studies and post-colonial criticism. Their works traverse disciplines of sociology, anthropology, to history, literary, and media studies and reveal how "gender" as a category does not obviate the study of women's history or practices of representing women, but, rather, gender can provide a methodology for working with texts that mark a power structure by and through body, sex, or science (Butler 1996; Lorber 2006). In other words, taking gender as a category, we will not eliminate the study of women, but rather we will be able to "name a social relation that subjects often experience as organic, ingrained, 'real,' invisible, and immutable" (Halberstam 2014). In terms of what I am interested here, I am asking, how can we use gender as a prism to understand something new about the discourse of superstitions in modern China? Here I provide a preliminary example of how literary analysis through the prism of gender could help us learn something new about colonial modernity in general, and the ways in which superstition functioned as a discursive construct in particular. I do this by offering a new reading of arguably the first feminist manifesto in Chinese history.

The Women's Bell (女界鍾 Nüjie Zhong, (Jin 2003)) was written by Jin Tianhe (1874-1947), a late Qing scholar and political figure in 1903. A rather lengthy essay initially published by Datong Shuju, this work was widely read and reprinted in successive editions in China and Japan. In this treatise, Jin Tianhe blatantly attributes China's national plight to the dire condition of its women whom he describes as psychically shackled to the household and mentally shackled by their lack of education and knowledge about the world:

my two hundred million sister compatriots, however, are still kept as ignorant as before, in chains and fetters, obsessed with dreams in winter and wallowing in melancholy in spring, knowing nothing of the ideas of equality between men and women or ideas of women's participation in politics that are held by free people in civilized nations. (Jin 2013, p. 208)

In a chapter titled "Women's Character", (nüzi zhi pinxing), Jin Tianhe details what he views as the character of Chinese women. Specifically, Jin focuses on characteristics that hinder Chinese women's development. Among these aspects are the evil of footbinding, the evil of ornamentation, and the evil of superstition. The section on superstition opens with predictable verbiage where the writer explains women as fountains of emotional excess. Jin writes:

How does superstition develop? It starts from human feelings and hopes, and women are factories of feelings and hopes. In barbaric times, women were mentally weaker than men, and so they became accustomed to depending on men. They counted on men to deliver those feelings and hopes they wished for and could expect to obtain. And they counted on the gods to grant them those feelings that were out of their control. (Jin 2013, p. 225)

Jin Tianhe reiterates familiar binaries to explain superstition as the locus of the unquantifiable, what is beyond human control-between women and men, feelings and facts. In another section, Jin adds to the list of binaries the contrast between "religion" and "superstition":

superstition among Chinese women has more than one source. I will sum it up in two sentences: the daily talk of fate is the warp, and the Buddhist talk of the field of merit and blessing from the Buddha are the woof ... I want to destroy superstition in women, reverse its course and use their talents and apply them to a sense of patriotism and concern for the world. Reading everyday about Columbus and Magellan is not as good as carrying out the work of Confucius and Magellan. Praising Confucius and [Jesus] Christ every day is not as good as carrying out the work of Confucius and Christ; Chanting every day for the master of the Universal Gate or Saintly Mother of Mei Island is not as good as carrying out the work of a master or a saintly mother for oneself. With willow sprig in hand, spread the nectar of the gods across the three thousand galaxies; let down your hair, carry a sword, and travel the seas, and see with knowing eyes the sufferings of all sentient beings. Good women, good women, use my words to determine whether you are honest or not, believers in the way or not. (Jin 2013, pp. 226-27) 
Here Jin Tianhe clearly employs the missionary distinction between "superstition" and "religion", by distinguishing true religious practice from chants and talk of fate. Moreover, Jin Tianhe demonstrates the extent to which the discourse on superstition was thoroughly gendered by addressing his potential readers with the term "good women" Shannü-a Buddhist designation for laywomen in the audience for Buddhists sermons, who are able to fully grasp Buddhist teachings as the result of good deeds they did in their former existences. Situating himself as the voice of authority: "use my words to determine whether you are honest or not-" Jin Tianhe inscribes relations of power in the difference between "good women" and chanters of prayers, receivers of blessings. It is thus surprising, considering the efforts Jin locates in promoting these binaries between correct belief and superstition to see that in the same narrative, Jin Tianhe's rhetoric is also brimming with terms which validate practices that he himself considers superstitions:

... superstition is an inauspicious thing (mixin zhe bu xiang zhi wu ye). Nuns, witches, geomancers, and astrologers are inauspicious people. I do not understand why for an auspicious matter like marriage people defer to the monastery and ask for strips of paper? (Jin 2013, p. 226)

How are we to reconcile the failure of Jin Tianhe's argument here? If superstitious practices are merely a manifestation of emotional excess and have no grasp upon facts, how can something be auspicious or inauspicious? Why use the term xiang (usually translated as auspicious)—which semantic resonance throughout Chinese history derives from divination-a practice Jin condemns? How can we resolve these contradictions? One could argue that Jin Tianhe simply falls back to a figurative domain which is familiar to him and that would explain these contradictions. But I believe there is more here than a slip of the tongue. What we see in Jin Tianhe's prose is form and content working against each other. To the reader, this tension between form and content in The Women's Bell reveals how gender signifies relations of power-not as a one-way oppression-what we might sometimes imagine patriarchy is—but in more nuanced dynamics; where the act demarcating difference, between civilized and barbaric, man and woman, worthy deeds and superstitious practice, often fails.

I anticipate two main advantages in reading for such disjuncture between content and form in other texts. First, this strategy can help us learn how colonial epistemology was negotiated by its addressees. Inconsistencies of this sort are pervasive in modern Chinese fiction where superstitions often demonstrate simultaneously wretchedness and feudalism alongside magical power and desirability. We could then shed new light on the circulation of concepts in modern Asia, not as a story of disenchantment nor re-enchantment but as a multiplicity of discursive functions which are tied to one another and often work against each other: one cannot understand the discourse on superstition outside the paradigm of civilization with its strong connections to proto-feminist movements in the metropoles. Second, this type of reading will not only help us to understand the discourse on superstition in modern China-a discourse that had been ubiquitous across media and fields from law to governance to culture-in a new way, but will also enable us to think about gender as more than the position of women in Chinese society. It is through Jin Tianhe's manifesto that we can see how mixin was used to signify relations of power and also how it failed in demarking these relations. As such, the problem of translating a discourse on superstition in Chinese modernity can illuminate how gender functions as constitutive element of social relationship by establishing and undoing binaries, between men and women between natural and supernatural between logic and faith. I would like to conclude this essay by demonstrating more elaborately how content and form disjuncture operate in what is probably the most well-known story about superstitions in modern Chinese literary oeuvre, Medicine by Lu Xun.

\section{Content and Form in Lu Xun's Medicine}

The most important writer of the May Fourth generation, immortalized as the father of modern Chinese literature, Lu Xun (1881-1936), wrote the short story Medicine in 1919, at the beginning of his writing career. It remains one of his most widely-read stories and is often cited as an emblem 
of May Fourth rebellion against traditional Chinese medicine and pre-twentieth century folk beliefs. The story is set in late Qing rural China, where the impoverished parents of little Shuan-Old Shuan and Old Shuan's wife-spend their last dime on what promises to be a life-saving medicine for their ill son. The medicine turns out to be a steamed bun dipped in the blood of a recently executed anti-Manchu revolutionary by the name of Xia Yu. Little Shuan consumes it in full, fueling the hopes of his parents for his speedy recovery. The text is divided into four parts. The first three parts unfold chronologically during one day, commencing in the early dawn, as Old Shuan leaves his home to purchase the blood-soaked bun and concluding after Little Shuan consumes the medicine, and the family await its work. The fourth section fast forwards to several months later. It is Tomb-Sweeping Day (qing ming jie) and Old Shuan's Wife is at the cemetery. The reader pieces together the missing information and learns that she is there to perform the yearly rituals for the dead, such as cleaning the grave and burning paper money for the safe travel of the deceased in the other world, at her son's grave. Another aging woman appears, she is the mother of the executed revolutionary. The two women find a wreath of red and white flowers that is placed on the grave of the executed. Dumbfounded as to who could have placed the wreath there, the executed revolutionary's mother believes that the spirit of her dead son who cannot find rest in the afterlife sent the wreath to her. Desperately attempting to verify her intuition, she addresses her son: "if you are really here, and can hear me, make that crow fly on to your grave as a sign (Yang and Yang 1980, p. 67)." As time passes and the crow remain still, Old Shuan's wife convinces the woman to go back home. At that moment, as they begin to head back, the crow takes flight "like an arrow towards the far horizon (Yang and Yang 1980, p. 67)".

Lu Xun's indictment of traditional Chinese medicine is well-known. The literary paragon opened the preface to his first collection of short stories in which Medicine is included, with a childhood memory. Lu Xun was sent to the local doctor every day to purchase various medicines for his ailing father. Dwindling the family funds, the medicines all proved ineffective, and his father passed. His death urged the young Lu Xun to pursue studies of Western medicine in Japan-a course he then famously abandoned to embark on a writerly career. The voice of the writer who denounced folk beliefs notwithstanding, more recent studies establish the persisting presence of an otherworldly realm - beyond the explaining capabilities of pure reason—in Lu Xun's writing, in ways that make it impossible to understand his literary career as a simple embrace of the touted May Fourth "Mr. Science and Mr. Democracy" (Liu 2009; Ying 2016). Reading Medicine along these lines, the reader finds frequent conjuring of ghosts and spirits particularly through the point of view of the boy's father, Old Shuan. During his journey to purchase the medicine, Old Shuan "looked around and saw many people, strange people, in twos and threes, wandering about like ghosts. However, when he gazed steadily at them, he could not see anything else strange about them (Yang and Yang 1980, p. 59).12" Depictions such as this had been read as marking the "superstitious masses" (Xu 1999, p. 71). But the pervasiveness of imaginations of ghosts and demons in this story suggests that they have a role more substantial than circumscribing China's superstitious population. The invocation of other worldly beings via the consciousness of Old Shuan charts a human experience of the numinous and recognizes the wavering of such experience between thresholds of what is real and what is imagined. This wavering between different types of reality is key to our understanding of this story and of the choice Lu Xun made here- to grapple with the discourse on superstition in a short story. The undoing of the boundaries between a reality in which ghosts are a backward superstition and one that is infused by other-worldly realms takes shape here in tension between content and form, which culminates with the characters of the two mothers in the final scene at the grave yard as they discover the wreath.

$\mathrm{Lu}$ Xun mentions the red and white wreath that appears on the grave of the martyr Xia Yu "from nowhere" (Yang and Yang 1980, p. 38) in his preface to Call to Arms (Na Han 1922), the volume

12 I modified Yang and Yang's translation slightly. They write: "wandering about like lost souls" but whereas "lost souls" can carry various meanings in English, the Chinese original specifically describes a scene in which ghosts pace back and forth restlessly "san san liang liang, gui si de zai nali paihuang". (Yang and Yang 1980). 
in which Medicine was first published. He relates that the appearance of the wreath represents a literary device he invented, which he terms qubi-translated by Marston Anderson as "distortions" (Anderson 1990). Lu Xun explains that he was concerned his fiction is too pessimistic - that his realist depictions of Chinese society would not inspire reform but despair-so he placed a wreath of flowers as something that disrupts the finality of death, and that he used such "distortions" in other stories as well (Yang and Yang 1980, p. 38). This interpretation by the author has troubled scholars who argue that the facts the wreath has no roots and the crow does not take flight upon request render the scene at the cemetery a futile attempt to lean on superstitious practices (Xu 1999; Harpham 2013). Yet, Lu Xun's distortions could also be understood differently: not only as disruption to the unity of the realist narrative, but as a way to intensify tension between content and form. The content of Medicine tells of a failed society-failing at recognizing a chance for true change by executing its harbinger and failing at guarding the lives of its most vulnerable members. But elements that lie outside the plot trouble this narrative. The medicine-a blood-soaked bun-indeed fails, but its symbolic value as means of healing-indexed by the whiteness of bread and the redness of blood, food in which he who ate becomes that which will be eaten-refuses to die out. The symbolic blood-soaked bun appears twice more in the final scene. First, in the imagery describing the graveyard: "The serried ranks of grave mounds on both sides looked like the rolls [mantou] laid out for a rich man's birthday" (Yang and Yang 1980, p. 65). Then, finally, the image of the bun reincarnates in the circular shape of the wreath with the striking colors of red and white. As such, the body of the martyr transforms twice: to a blood-soaked bun and to a red and white round wreath. When the two mothers of the two victims of traditional society-the revolutionary and the young boy-come together to perform rituals of mourning, form literally takes over content by redrawing narrative space, altering a blood-soaked bun to a circular wreath that appears of nowhere. In its reincarnation, the medicine-a deadly superstition-summons the space of the yet unknown, of another world. The two mothers, united in loss and grief are the ones through which this space is made possible.

Lu Xun, we know, was critical of the liberal May Fourth call for women's rights, which, he was aware, had more relation to nationalist pursuits than to any faithful attempt to understand the plight of actual women. Yet, despite the fact Lu Xun was keenly perceptive of and wrote extensively against the voyeurism and hypocrisy which conjured up modern images of liberated women in cinema and the newspapers (his eulogy to the Shanghai cinema star Ruan Linyu who took her own life in 1935 is a famous example), Eileen Cheng suggests that female characters in Lu Xun's fiction do not display an agentic position, and the author's "deeply sympathetic portrayals of feminine suffering, submission and self-effacing sacrifice along with his scrupulous attempts to avoid unseemly associations to the (not necessarily 'chaste') women in his fictional and non-fictional depictions, share much in common with lauded models of traditional femininity found in classical texts" (Cheng 2013, p. 101). Cheng's observation is important: female agency is missing in Lu Xun's fiction-in Medicine for example, the narrator focalizes Old Shuan from within: his emotions and thoughts are elaborately depicted. The boy's mother, on the other hand, is focalized from outside-described by her actions. The reader does not get a sense of an agentic character. ${ }^{13}$ Yet, similarly to how Medicine is not a simple admonition of a China's traditional culture, it is also not simply a depiction of illiterate women worshipping and clinging to their superstitions in vain. As in the case of the blood-soaked bun that reappears within the structure of the text, Lu Xun troubles the distinction between men and women through form: by encoding a contemporary female revolutionary within the character of Xia Yu.

13 Probably the most glaring example of a female protagonist who lacks a sense of agency is Xianglin's Wife in the short story New Year's Sacrifice (Zhufu 1925). This story, which Cheng also mentions in this respect, tells of a woman whose life is ridden with tragedy from widowhood to child bereavement, to poverty and death. In the narrative, Xianglin's wife is described through the point of view of the narrator or the village folk. Her obsessive telling and re-telling of how she lost her son render her mad to the town's people, and empties her agency even further, emphasizing the cruelty of the country folk and the ineptitude of the young narrator to alleviate her plight. 
The character of the executed revolutionary, Xia Yu, alludes to the well-known late Qing female Anti-Manchu martyr ${ }^{14}$, Qiu Jin (1875-1907), who was executed in Shaoxing for her part in a plan to assassinate Qing government officials. The allusion is invoked both by the Chinese characters Lu Xun uses to name 夏瑜Xia Yu—literally meaning summer and jade. These characters connote the characters Qiu 秋 (autumn) and Jin 瑾 (another term for jade) which form the anti-Manchu martyr's name. Moreover, on his way back from purchasing the bun soaked with blood of the executed, Old Shuan passes by a sign that reads 古亭口 gu ting kou. This sign references the location of Qiu Jin's execution in Shaoxing, Zhejiang. Lu Xun carefully encodes the location in the story by depicting Old Shuan reading a faded golden inscription in which a character is missing: 軒 xuan. It is the reader's task to decode what the sign means and conjure the figure of Qiu Jin from that location.

The real Qiu Jin was a young woman who famously left her husband and two children and traveled to Japan in search of modern education and political activism. There, she became well-known among Chinese students for actively participating in the ethno-nationalist movement to overthrow the Manchu dynasty and establish a Han government. Lu Xun attended one of her lectures where she encouraged the Chinese students present to return to China and aid in overthrowing the Qing dynasty. Qiu Jin was a prolific writer, and she wrote extensively on the plight of Chinese women. Often mentioned today as the first Chinese feminist, Qiu Jin operated in the same Tokyo social circles as Jin Tianhe, writer of The Women's Bell. Her writing helped shape the liberal discourse which saw the woman question as a national problem, the solution to which-abolishing foot binding and encouraging female education-would lead to China's progress. Qiu Jin was known for having a flair for the dramatic. She was famous for her penchant for cross-dressing, for carrying and brandishing swords and for making bombs. Photographic images of her in men's clothing circulated in newspaper and contributed to her popularity among Chinese Youth. In time, these images and Qiu Jin's unusual life story solidified her position as a heroine martyr of the revolution. Lu Xun was both preoccupied with and ambivalent toward the historical Qiu Jin, whom he mentions in various writings. He was critical of the star cult created around Qiu Jin, as well as of Qiu Jin's clear embrace of the attention lavished upon her (Lu Xun famously stated that Qiu Jin was clapped to death) (Cheng 2013). Why, then, would Lu Xun opt to embed Qiu Jin in his narrative? And why would he encode her life in those of a fictional male revolutionary? As a symbol of the new woman, touted as such by media coverage and immortalized as such by the May Fourth, what do we make of Qiu Jin's transformation to a blood-soaked bun and to a red and white wreath?

Rather than using Qiu Jin to offer his two cents on the question of women's liberation, I suggest, $\mathrm{Lu}$ Xun encodes Qiu Jin in the form of this story to offer his view on the discourse on superstition. Knowledgeable as he was of the liberal view of women's liberation, which defined Chinese women as superstitious primitives in dire need of reform (Qiu Jin herself noted as such, in her short novel Stones of the Jingwei Bird), Lu Xun, in the story, transforms the spokesperson for women's liberation into a superstition, only to destabilize its falsity in the cemetery scene. By encoding Qiu Jin inside a male body—in a way extending her cross-dressing affinity to its finality - Lu Xun indexes the problem of superstition not as a problem of women's liberation but as a concept which, like gender, works to inscribe power relations in society.

As a woman or a man, the revolutionary meets his or her end in the most visceral way: they are eaten up. At the end of it all, two mothers gaze at the body reincarnated as a red and white wreath. When the crow takes its flight finally, both too late and somehow still on time-while the believer is still there- the reader witnesses the power of fiction to embody several thresholds of reality at the same time. Medicine is the story of a couple that spends their last coins on a superstition, bringing calamity upon their son. Medicine is also the story of a revolutionary martyr, who, via literary "distortions", embodies in a red and white wreath the possibility for the superstition's validity: for 
an otherworldly realm, without which, as Lu Xun himself pointed out, there is no room for hope, for conceiving a different reality, for a revolution. Finally, Medicine is a code: it invites the reader to decode a message conveyed through missing Chinese characters and characters which connote other characters-signifiers leading to more than one signified. This message embeds a female revolutionary in a story about a male revolutionary through form itself. What Medicine finally does is to undo binary distinctions. The content of Medicine resists superstition as deadly and features women as the active practitioners of primitive folk customs. But form then reifies a realm of possibility for a different reality. Gender evinces the reality of superstition not by casting it as a female practice but by using superstition to challenge the binary distinction between a rational reality and a supernatural one as between the gendered body of male and female: both form the revolutionary body of the martyr. Gender difference is challenged by the ultimate cross-dressing: embedding the woman martyr within the story of the male martyr-making the gender of this character completely fluid, so much so that it is transformed into a metonymy - a wreath which replaces the body and leaves a hope. In this sense, Medicine inhabits the powerful discourse against superstitions but also their ongoing allure.

\section{Conclusions}

To us readers, Medicine offers an opportunity to learn something about a ubiquitous discourse on superstition in Republican China. If we employ literary analytical tools in our reading, we simply cannot place Medicine's engagement with mixin within a narrative of Chinese disenchantment, or a Chinese re-enchantment, because the story grapples with more possibilities than those. Like the unintentional undoing of his own rhetoric, which crept upon Jin Tianhe's self-celebratory calls for women to let down their hair and carry a sword, Medicine undoes the contours of its own reality. It shows how fiction captures the ways in which powerful discursive formations (women's liberation and civilization) interlink to constitute a certain reality, all while making room for another reality beyond what is known. Literature can do that by its very nature which makes it believable and fictional at the same time, and by the properties of literary expression to facilitate tensions between what is said and how it is said. For this reason, in this essay, I tried to make a case for approaching literary texts and literary methodology to tap into the multilayered facets that characterized the circulation of "superstition" in China and elsewhere. While this essay offers a new such understanding of Lu Xun's canonical short story, similar instances of gendered superstitious elements are legion in Chinese literature in both the modern and the contemporary era (I mentioned some of them in the beginning of section two). Now, it is up to us as readers to approach anew the trove of modern and contemporary Chinese literature, so that we could learn not only what superstition means, but also how different modes of expression address and negotiate it in different ways.

Funding: This research received no external funding.

Conflicts of Interest: The author declares no conflict of interest.

\section{References}

Anderson, Marston. 1990. The Limits of Realism: Chinese Fiction in the Revolutionary Period. California: University of California Press.

Anidjar, Gil. 2006. Secularism. Critical Inquiry 33: 52-77. [CrossRef]

Ashiwa, Yoshiko, and David L. Wank, eds. 2009. Making Religion Making the State: The Politics of Religion in Modern China. Stanford: Stanford University Press.

Bastid-Bruguière, Marianne. 1998. Liang Qichao yu zongjiao wenti. Tōhō Gakuhō 70: 329-73.

Blumberg, Hans. 1985. The Legitimacy of the Modern Age. Cambridge: MIT Press.

Broy, Nikolas. 2016. Civilization, Progress, and the 'Foul Stench of Religion': The Concepts of 'Religion' and 'Superstition' in the Politics of Modern East Asia. In Religion, Place and Modernity: Spatial Articulations in Southeast Asia and East Asia. Edited by Michael Dickhardt and Andrea Lauser. Leiden: Brill, pp. 37-68. 
Butler, Judith. 1996. Burning Acts, Injurious Speech. Chicago: The University of Chicago Law School Round, pp. 199-221.

Cass, Victoria Baldwin. 1999. Dangerous Women: Warriors, Grannies, and Geishas of the Ming. Lanham: Rowman and Littlefield.

Chakrabarty, Dipesh. 2000. Provincializing Europe: Postcolonial Thought and Historical Difference. Princeton: Princeton University Press.

Chatterjee, Partha. 1989. The Nationalist Resolution of the Woman Question. In Recasting Women: Essays in Indian Colonial History. Edited by Kumkum Sangari and Sudesh Vaid. New Bruns: Rutgers University Press.

Cheng, Eileen J. 2013. Literary Remains: Death, Trauma, and Lu Xun's Refusal to Mourn. Honolulu: Hawaii University Press.

Choi, Hyaeweol. 2009a. "Wise Mother, Good Wife": A Transcultural Discursive Construct in Modern Korea. Journal of Korean Studies 14: 1-33. [CrossRef]

Choi, Hyaeweol. 2009b. Gender and Mission Encounters in Korea. Berkeley: University of California Press.

Chu, Pingyi. 2018. Against Prognostication: Ferdinand Verbiet's Criticism of Chinese Mantic Arts. In Coping with the Future: Theories and Practices of Divination in East Asia. Edited by Michael Lackner. Leiden: Boston: Brill, pp. 433-50.

Conroy-Krutz, Emily. 2015. Christian Imperialism: Converting the World in the Early American Empire. Ithaca: Cornell University Press.

Crosby, Christina. 1991. The Ends of History: Victorians and the Woman Question. New York: London: Routledge.

Duara, Prasenjit. 1995. Rescuing History from the Nation: Questioning Narratives of Modern China. Chicago: Chicago University Press.

Federici, Silvia. 2014. Caliban and the Witch: Women, the Body and Primitive Accumulation. New York: Autonomedia.

Frazer, James. 1993. The Golden Bough: A Study in Magic and Religion. Ware, Hertfordshire: Wordsworth Editions. First published 1990.

Goossaert, Vincent. 2006. 1898: The Beginning or the End for Chinese Religion? Journal of Asian Studies 65: 307-35. [CrossRef]

Goossaert, Vincent, and David Palmer. 2011. The Religious Question in Modern China. Chicago: Chicago University Press.

Gordon, Ann D. 1997. The Selected Papers of Elizabeth Cady Stanton and Susan B. Anthony. New Brunswick: Rutgers University Press, vol. 1.

Halberstam, Jack. 2014. Gender. In Keywords for American Cultural Studies, 2nd ed. Edited by Bruce Burgett and Glenn Hendler. New York: New York University Press, Available online: https://proxy.library.mcgill.ca/ login?url=https://search.credoreference.com/content/entry/nyupacs/gender/0?institutionId=899 (accessed on 3 October 2019).

Harpham, John Samuel. 2013. “A Fierce Silence Falls": Lu Xun's Call to Arms. Criticism 55: 95-118. [CrossRef] $\mathrm{Hu}$, Shi. 1922. Jidujiao yu zhongguo [Christianity and China]. Shengming 2: 3-4.

Huang, Ko-wu. 2016. The Origin and Evolution of the Concept of mixin (superstition): A Review of May Fourth Scientific Views. Chinese Studies in History 49: 54-79.

Hughes, Aaron W., and Steven Ramsey, eds. 2018. The Superstition, Secularism and Religion Trinary: Or Re-Theorizing Secularism [special issue]. Methods $\mathcal{E}$ Theory in the Study of Religions 30: 1-20.

Jin, Tianhe. 2003. Nüjie Zhong. Shanghai: guji chubanshe.

Jin, Tianhe. 2013. The Women's Bell. In The Birth of Chinese Feminism Essential Texts in Transnational Theory. Edited by Lydia H. Liu, Rebecca E. Karl and Dorothy Ko. New York: Columbia University Press.

Josephson, Jason Ānanda. 2012. The Invention of Religion in Japan. Chicago: University of Chicago Press.

Josephson Storm, Jason A. 2017. The Myth of Disenchantment: Magic, Modernity, and the Birth of the Human Sciences. Chicago: Chicago University Press.

Judge, Joan. 2008. The Precious Raft of History: The Past, the West and the Woman Question in China. Stanford: Stanford University Press.

Ko, Dorothy. 2007. Cinderella's Sisters: A Revisionist History of Footbinding. Los Angeles: University of California Press.

Kuo, Ya-Pei. 2013. 'Christian Civilization' and the Confucian Church: The Origins of Secularist Politics in Modern China. Past and Present 218: 235-64. [CrossRef]

Latour, Bruno. 1993. We Have Never Been Modern. Cambridge: Harvard University Press. 
Lee, Haiyan. 2005. Tears That Crumbled the Great Wall: The Archaeology of Feeling in the May Fourth Folklore Movement. The Journal of Asian Studies 64: 35-65. [CrossRef]

Lee, Haiyan. 2014. The Stranger and the Chinese Moral Imagination. Stanford: Stanford University Press.

Liang, Qichao. 1999. Bao jiao fei suoyi zun kong lun. In Liang Qichao Quan Ji. Edited by Yang Gang and Wang Xiangyi. Beijing: Beijing Chu Ban She, vol. 1, pp. 762-70.

Liu, Lydia. 2009. Life as Form: How Biomimesis Encountered Buddhism in Lu Xun. Journal of Asian Studies 68: 21-54. [CrossRef]

Liu, Lydia He, Rebecca E. Karl, and Dorothy Ko. 2013. The Birth of Chinese Feminism Essential Texts in Transnational Theory. New York: Columbia University Press.

Lorber, Judith. 2006. Shifting Paradigms and Challenging Categories. Social Problems 53: 448-53. [CrossRef]

Lu, Xun. 1981. Lu Xun Quanji. Beijing: Renmin Wenxue Chubanshe, vol. I.

Margel, Serge. 2005. Superstition: L'anthropologie du religieux en terre de chréntienté. Paris: Éditions Galillée.

Martin, Dale. 2004. Inventing Superstition: from the Hippocratics to the Christians. Cambridge: Harvard University Press.

Masuzawa, Tomoko. 2005. The Invention of World Religions: Or, How European Universalism Was Preserved in the Language of Pluralism. Chicago: University of Chicago Press.

Mill, John Stuart. 1869. The Subjection of Women. London: Longman, Green, Reader and Dyer.

Nedostup, Rebecca. 2009. Superstitious Regimes: Religions and the Politics of Chinese Modernity. Cambridge: Harvard East Asian Monographs.

Nedostup, Rebecca. 2014. The Transformation of the Concept of Religion in Chinese Modernity. In Religious Diversity in Chinese Thought. Edited by Perry Schmid-Leukel and Joachim Gents. Chicago: Chicago University Press, pp. 148-65.

Ni, Zhange. 2015. The Pagan Writes Back: When World Religion Meets World Literature. Charlottesville: University of Virginia Press.

Nieh, Hualing. 1976. Sanqing Yu Taohong. Hong Kong: Youlian chubanshe.

Pang, Laikwan. 2004. Magic and Modernity in China. Positions: East Asian Cultures Critique 12: 299-327. [CrossRef]

Pollard, Lisa. 2005. Nurturing the Nation the Family Politics of Modernizing, Colonizing, and Liberating Egypt. 1805-1923. Oakland: University of California Press.

Qiu, Jin. 1997. Stones of the Jingwei Bird. In Writing Women in Modern China. Edited by Amy D. Dooling and Kristina M. Torgeson. New York: Columbia University Press, pp. 43-78.

Ramsey, Kate. 2011. The Spirits and the Law: Vodou and Power in Haiti. Chicago: Chicago University Press.

Scott, Joan. 1986. Gender: A Useful Category for Historical Analysis. The American Historical Review 91: 1053-75. [CrossRef]

Sneider, Allison L. 2008. Suffragists in an Imperial Age: US Expansion and the Woman Question 1870-1929. Oxford: Oxford University Press.

Spencer, Herbert. 1851. Social Statics or the Conditions Essential to Human Happiness Specified, and the First of them Developed. London: John Chapman.

Stanley, Brian. 1990. The Bible and the Flag: Protestant Missions and British Imperialism in the Nineteenth and Twentieth Centuries. Leicester: Apollos.

Stanton, Elizabeth Cady. 1997. Address on Women's Rights. In The Selected Papers of Elizabeth Cady Stanton and Susan B. Edited by Gordon Ann D. New Brunswick: Rutgers University Press, vol. 1, pp. 94-123.

Styers, Randall G. 2004. Making Magic: Religion, Magic and Science in the Modern World. Oxford: Oxford University Press.

Towns, Ann. 2009. The Status of Women as a Standard of Civilization. European Journal of International Relations 15: 681-706. [CrossRef]

Uno, Kathleen. 2005. Womanhood, War and Empire: Transmutations of "Good Wife, Wise Mother" Before 1931. In Gendering Modern Japanese History. Edited by Barbara Molony and Kathleen Uno. Cambridge: Harvard East Asian Monographs, pp. 493-519.

Wang, Xin. 2017. Wan qing xiaoshuo Zhong de fan mixin ticai chuyi. Wuhan ligong daxue xuebao 4: 214-19.

Wheatley, Jeffrey. 2018. US Colonial Governance of Superstition and Fanaticism in the Philippines. Method and Theory in the Study of Religion 30: 21-36. [CrossRef]

Xu, Dishan. 1945. Fuii mixin de yanjiu. Taiwan: Shangwu yinshuguan. First published 1941.

Xu, Jian. 1999. The Will to the Transaesthetic: The Truth Content of Lu Xun's Fiction. Modern Chinese Literature and Culture 11: 61-92. 
Yang, Xianyi, and Gladys Yang. 1980. Lu Xun Selected Works, Volume One. Beijing: Foreign Language Press.

Yi, Ying. 2013. Lun zhongguo xiandai zuojia dui minjian wugui Xinyang de shuxie. Zhongguo Xiandai Wenxue Yanjiu Congkan 7: 92-99.

Ying, Lei. 2016. Lu Xun, the Critical Buddhist: A Monstrous Ekayāna. The Journal of Chinese Literature and Culture 3: 400-28.

Zeitlin, Judith. 1998. Spirit Writing and Performance in the Work of You Tong 尤侗 (1618-1704). T'oung Pao 84: 102-35. [CrossRef] article distributed under the terms and conditions of the Creative Commons Attribution (CC BY) license (http://creativecommons.org/licenses/by/4.0/). 